\title{
Appraisal of the Level of Coordination among Solid Waste Management Agencies in Zaria Urban Area, Kaduna-Nigeria
}

\author{
Tpl. Lawal Kabir Tunau and \\ Tpl. Moses Zira Wanda \\ Corresponding Author: \\ Department of Urban and Regional Planning, \\ School of Environmental Science Technology \\ Federal Polytechnic, Mubi Adamawa - Nigeria.
}

\begin{abstract}
The paper is aimed at determining the level of coordination that exists among the different agencies that are involved in solid waste management in Zaria Urban area. Structured questionnaire and literature review were used to obtain data and information on the roles and responsibilities of agencies involved in solid waste management as well as the nature of inter-agency relationship in the study area. Purposive sampling technique was used to select 13 representatives of the Solid Waste Management agencies. Methods of data analysis employed for the research were the descriptive statistics (frequency analysis, percentage distribution, mean scores, grand mean scores and content analysis) for both government agencies and formal private waste collectors. The two points ordinal scale 1 representing yes and 2 representing no was employed for obtaining information on inter-agency relationships while the multiple options likert scale format was used for obtaining information on the level of coordination that exists among the different agencies, using such indicators as collaboration, consultation and information exchange. The multiple options likert scale questions type was also used to obtain information on effects of absence of a well-coordinated solid waste management system within the study area. The results of the analysis of the indicators of coordination using the two points ordinal scale on inter-agency relationship and other indicators, that is collaboration, consultation and information exchange also signified inefficient coordination among the agencies. The paper recommended among others that, there is need to prepare a well-coordinated and common solid waste management plan for common implementation by all stakeholders, which will guide policy formulation and coordinate all urban solid waste management issues within the urban area and also information exchange should be improved by providing effective means of communication among the institutions in the areas of public awareness campaigns, regularity of accessibility of the institutions to up to date information from other institutions.
\end{abstract}

Keywords:- Solid Waste Management, Coordination, Information Exchange, Collaboration, Consultation.

\section{INTRODUCTION}

Today, there are certain common nations about how solid waste management should be governed, where National governments are expected to formulate policies and established the institutional and legal frameworks while local governments provide or manage solid waste collection and disposal services (Taylor, 2000). The private sector and community groups, organizations or leaders are to be directly involved in the management of the sector through partnerships, while cooperation is needed from individuals or households in areas such as payment for services and proper waste handling practices. However, the situation in Nigeria does not reflect this trend, as the management of solid waste is far from being satisfactory (Taylor, 2000). Many parts of the cities and towns including Zaria Urban Area do not benefit from any organized waste management services and therefore waste are unattended to, burnt or disposed of haphazardly (Stare,2005).

The current municipal solid waste management crisis being faced in Nigeria is an indication of the failure of the existing management systems. Government has attributed the situation to the inadequacy of funds to buy the necessary equipment needed for waste collection and disposal and the increasing uncooperative attitude of the public in keeping the environment clean among others (Yahaya,1999). In the past, research works and publications for instance, Shubeler (1996) has identified weak management capacity and poor financial base respectively as the major reasons for increasing failure in waste management and other environmental problems. In recent years, municipal solid waste management has attracted increasing attention from bilateral and multilateral development agencies, due to the mounting urgency of urban environmental problems and increasing concern for capacity building at the level of municipal management (Shubeler, 1996). The good governance campaign is often promoted by the World Bank and donor agencies as a way of handling the numerous challenges facing African governments, including service delivery. A major expectation of the campaign is that local governments manage the urban development process in conjunction with an array of institutions ranging from the private sector to community groups and households (Onyanta, 2006). According to the UDBN (1998), there is no framework for 
joint action in Nigeria to tackle city wide problems and that initiatives from non-state actors remain adhoc and outside of the overall system of solid waste management, because of lack of comprehensive plan. Similarly, the two local governments' councils in Zaria urban area do not seem to work in a coordinated way due to this problem. The lack of a comprehensive policy on solid waste management may have several implications but a notable one is that it reinforces the exclusion of the poor from services. And as a result of lack of appropriate institutional and legal framework for solid waste disposal and management the existing laws have failed to solve the problems for which they were enacted

This paper focuses on Appraisal of the level of Coordination among Solid Waste Management Agencies in Zaria Urban Area, inorder to identify the problems related to the inter relationship that exists among solid waste management agencies and propose a system ensure efficient coordination among them.

\section{MATERIALS AND METHODS}

Data for this study was obtained by administering structured questionnaires to public agencies, which includes; Heads/Representatives of Kaduna State Environmental Protection Agency (KEPA) Public Health Departments of Zaria and Sabon-gari local Government Areas and formal private waste collectors which includes: DERIT CLIN, Dimension Waste, TJ LINKS, PECT, Adada Akara Entr. Nunab Nig. Ltd. Baba Kamfani Nig. Ltd. Danarewa Envt. Serv. Ltd, HB Multi-Purpose Serv. Nig. Ltd and Kyuriit Cleaners Nig. Ltd. Other source of data was review of literature; comprising of text books, journals, technical reports, internet search, published research works, unpublished research works and other viable sources.

Purposive sampling technique was used to select 13 representatives of the Solid Waste Management agencies. The likert scale was used; the choice of likert scale was because it enables the respondents to easily respond to the items. It allows the research to carry-out both qualitative and quantitative approaches effectively with the use of statistics for data interpretation, the likert scale ranged from ' 0 ' for undecided to ' 4 ' for strongly agree.

\begin{tabular}{|c|c|}
\hline Rating & Description \\
\hline $\mathbf{0}$ & Undecided (UD) \\
\hline $\mathbf{1}$ & Strongly disagree (SD) \\
\hline $\mathbf{2}$ & Disagreed (DA) \\
\hline $\mathbf{3}$ & Agree (A) \\
\hline $\mathbf{4}$ & Strongly Agree (SA) \\
\hline
\end{tabular}

Table 1:- Rating System for the Likert Scale

Source; Adapted from Galadima (2012)

In developing the structured questionnaire based on the likert scale. The variables were listed for which the respondents indicated their responses for each after which such respondents were ranked accordingly using the rating in table 1.
The indicators employed in appraising the level of coordination among solid waste management agencies includes the following: the nature of inter-agency relationships, collaboration, consultation and information exchange among agencies as detailed in table 2, below

\begin{tabular}{|c|c|c|}
\hline Indicators of coordination & Features of coordination & Tools of measurement \\
\hline Inter-agency relationships & $\begin{array}{c}\text { Mutual inter-dependence in carrying out } \\
\text { their roles/ responsibilities }\end{array}$ & $\begin{array}{c}\text { The 2 points ordinal scale '1' } \\
\text { representing yes and 2' representing no. }\end{array}$ \\
\hline Collaboration & $\begin{array}{c}\text { Clearly defined roles and responsibilities } \\
\text { of the agencies; negotiations } \\
\text { cooperation, ability to abide by the } \\
\text { specified tasks } \\
\text { scalestions type) }\end{array}$ & $\begin{array}{c}\text { Multiple choice questions (the likert } \\
\text { Complying with joint decisions etc. }\end{array}$ \\
\hline Consultation among agencies & $\begin{array}{c}\text { Regular participation in stake holders } \\
\text { workshops, seminars and other fora for } \\
\text { exchange of knowledge } \\
\text { Regular stakeholders joint meetings to } \\
\text { discuss issues of mutual interest }\end{array}$ & $\begin{array}{c}\text { Multiple choice questions (the likert } \\
\text { scale }\end{array}$ \\
\hline
\end{tabular}




\begin{tabular}{|c|c|c|}
\hline $\begin{array}{c}\text { Exchange of information among } \\
\text { agencies }\end{array}$ & $\begin{array}{c}\text { Regularity of accessibility of up to date } \\
\text { information from one stakeholder to } \\
\text { another }\end{array}$ & $\begin{array}{c}\text { Multiple choice questions (the likert } \\
\text { scale questions type) } \\
\text { Regularity of inter-agency } \\
\text { correspondences }\end{array}$ \\
Availability of internet service within the \\
agency \\
Regularity of public awareness \\
campaigns with regard to solid waste \\
management
\end{tabular} \mid

Table 2:- Indicators of Coordination among Solid Waste Management Agencies

Source; Adapted from Galadima (2012)

\section{STUDY AREA}

Zaria Urban Area is located between latitudes $10^{\circ} 57^{\prime} 36^{\prime \prime} \mathrm{N}$ and $11^{\circ} 15^{\prime} 32^{\prime \prime} \mathrm{N}$, longitudes $7^{\circ} 39^{\prime} 00^{\prime \prime} \mathrm{E}$ and $7^{\circ} 53^{\prime} 02^{\prime \prime} \mathrm{E}$. It is about $85 \mathrm{~km}$ north of Kaduna. The urban area is made up of two local governments areas of Sabon-Gari and Zaria (Fig.1) Zaria is one of the seven Hausa States, and it is situated in the southern part of Hausa land in Northern Nigeria. According to Ukoje, 2011, the present day Zaria urban area is formed by four distinct Urban sectors - Zaria City, Tudun-Wada, Sabon-Gari and Samaru (Fig. 1).

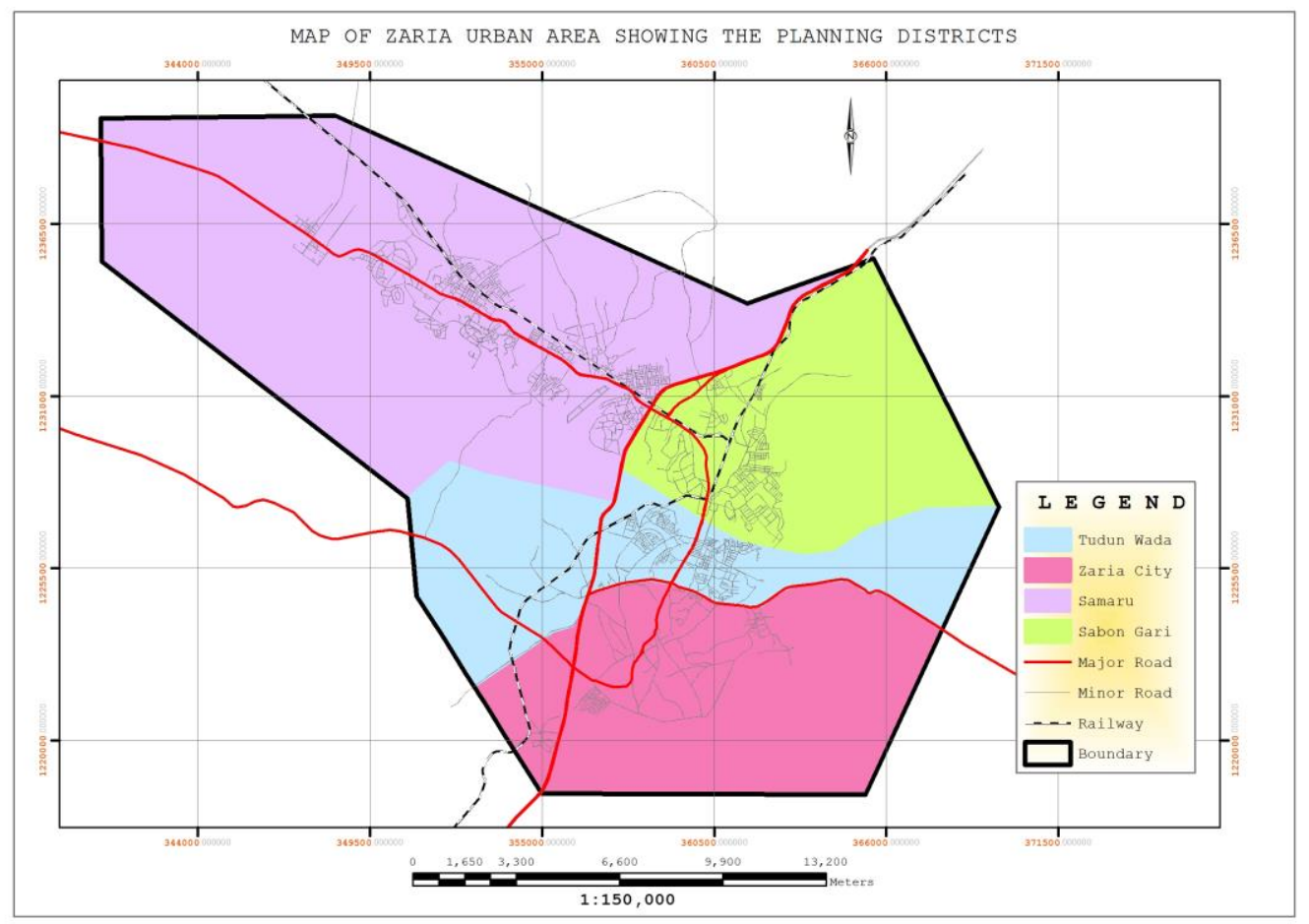

Fig 1:- Zaria Urban Area (Source: Google image, 2016)

\section{RESULTS AND DISCUSSION}

Methods of data analysis employed for the research were the descriptive statistics (frequency analysis, percentage distribution, mean scores, grand mean scores and content analysis) for government agencies and formal private waste collectors. The 2 point scale (based on yes /no response, developed from free response questions type) 1 representing relationship exists and 2 indicating that no relationship exists, which was meant to collect data about the inter-relationship among agencies involved in solid waste management was analysed by means of frequencies, means and grand means. The multiple option questions type (which was based on the likert scale) was used to collect data about interaction among agencies in the areas of consultation, collaboration and information exchange. These responses were analysed by the use of frequencies, mean scores and grand means while the descriptive statistics such as the likert scale through the application of frequency counts, mean scores and grand means were employed for analysing the data on the following; (a) Nature of relationship among the agencies responsible for solid waste management (b) analysis of data on the effects of absence of a well- coordinated solid waste management system in the study area. 
ISSN No:-2456-2165

\begin{tabular}{|c|c|}
\hline Scores & Description \\
\hline 0.00 to 0.29 & Little relationship \\
\hline 0.30 to 0.49 & Low relationship \\
\hline 0.50 to 0.69 & Moderate relationship \\
\hline 0.70 to 0.89 & High relationship \\
\hline 0.90 to 1.00 & Very high relationship \\
\hline
\end{tabular}

Table 3:- Decision Rule for the Two Points Scale

Source: Adapted from Galadima (2012)

Based on the decision rule on table 3 above, any means score of respondents between 0.00 to 0.29 was considered as little relationship, the mean score of respondents between 0.30 to 0.49 was low relationship, any means score between 0.50 to 0.69 was considered moderate relationship, a means score between 0.70 to 0.89 was considered as high relationship, While the mean score between 0.90 to 1.00 was considered as very high relationship.

\begin{tabular}{|c|c|c|c|}
\hline S/No & Agency & $\begin{array}{c}\text { Statutory Roles/Responsibilities } \\
\end{array}$ & Roles/Responsibilities Performed \\
\hline 1 & KEPA & $\begin{array}{l}\text { Regulate monitor activities of stakeholders, Arrange } \\
\text { for the collection \& disposal of waste. Supervision } \\
\text { \&enforcement of byelaws, Provision of land for waste } \\
\text { management infrastructure, Manages contracts b/w LG } \\
\text { Authorities \& private sector operators, Assisting in } \\
\text { capacity building }\end{array}$ & $\begin{array}{c}\text { Provision of land for waste management } \\
\text { infrastructure, Manages contracts b/w LG } \\
\text { Authorities\& private sector operators, } \\
\text { Registration \& supervision of solid waste } \\
\text { contractors }\end{array}$ \\
\hline 2 & $\begin{array}{l}\text { PHD. of Zaria } \\
\text { LG }\end{array}$ & $\begin{array}{l}\text { Locate, construct \& maintain convenient sites for } \\
\text { erecting refuse depots. Collaborate with other agencies } \\
\text { to collect \&dispose refuse or contracting evacuation of } \\
\text { waste dumps to private collectors. Maintain equipment } \\
\quad \text { \&facilities for waste management, Conducting } \\
\text { sanitation in every last week of the month. Supervision } \\
\text { of street sweeping \& drainage clearing }\end{array}$ & $\begin{array}{c}\text { Contracting evacuation of waste dumps to } \\
\text { private collectors. } \\
\text { Conducting sanitation in every last week } \\
\text { of the month. Supervision of street } \\
\text { sweeping \& drainage clearing }\end{array}$ \\
\hline 3 & $\begin{array}{l}\text { PHD. of Sabon } \\
\text { Gari }\end{array}$ & , $\quad$, $\quad, \quad$, & " \\
\hline 4 & DERIT CLIN & $\begin{array}{l}\text { Responsible for waste collection, Transportation, \& } \\
\text { disposal for profit }\end{array}$ & $\begin{array}{l}\text { Responsible for waste collection, } \\
\text { Transportation, \& disposal for profit }\end{array}$ \\
\hline 5 & $\begin{array}{l}\text { Dimension } \\
\text { Waste }\end{array}$ & $\begin{array}{l}\text { Responsible for waste collection, Transportation, \& } \\
\text { disposal for profit }\end{array}$ & $\begin{array}{l}\text { Responsible for waste collection, } \\
\text { Transportation, \& disposal for profit }\end{array}$ \\
\hline 6 & TJ LINKS & $\begin{array}{l}\text { Responsible for waste collection, Transportation, \& } \\
\text { disposal for profit }\end{array}$ & $\begin{array}{l}\text { Responsible for waste collection, } \\
\text { Transportation, \& disposal for profit }\end{array}$ \\
\hline 7 & PECT & $\begin{array}{l}\text { Responsible for waste collection, Transportation, \& } \\
\text { disposal for profit }\end{array}$ & $\begin{array}{l}\text { Responsible for waste collection, } \\
\text { Transportation, \& disposal for profit }\end{array}$ \\
\hline 8 & $\begin{array}{l}\text { Adada Akara } \\
\text { Entr. }\end{array}$ & $\begin{array}{l}\text { Responsible for waste collection, Transportation, \& } \\
\text { disposal for profit } \\
\text { Evacuation of waste dumps\& street sweeping for profit }\end{array}$ & $\begin{array}{l}\text { Responsible for waste collection, } \\
\text { Transportation, \& disposal for profit } \\
\text { Evacuation of waste dumps\& street } \\
\text { sweeping for profit }\end{array}$ \\
\hline 9 & $\begin{array}{l}\text { Nunab Nig. } \\
\text { Ltd. }\end{array}$ & $\begin{array}{l}\text { Responsible for waste collection, Transportation, \& } \\
\text { disposal for profit }\end{array}$ & $\begin{array}{l}\text { Responsible for waste collection, } \\
\text { Transportation, \& disposal for profit }\end{array}$ \\
\hline 10 & $\begin{array}{l}\text { Baba Kamfani } \\
\text { Nig. Ltd. }\end{array}$ & $\begin{array}{l}\text { Responsible for waste collection, Transportation, \& } \\
\text { disposal for profit }\end{array}$ & $\begin{array}{l}\text { Responsible for waste collection, } \\
\text { Transportation, \& disposal for profit }\end{array}$ \\
\hline 11 & $\begin{array}{c}\text { Danarewa } \\
\text { Envt. Serv. Ltd }\end{array}$ & $\begin{array}{l}\text { Responsible for waste collection, Transportation, \& } \\
\text { disposal for profit }\end{array}$ & $\begin{array}{l}\text { Responsible for waste collection, } \\
\text { Transportation, \& disposal for profit }\end{array}$ \\
\hline 12 & $\begin{array}{l}\text { HB Multi- } \\
\text { Purpose Serv. } \\
\text { Nig. Ltd } \\
\end{array}$ & $\begin{array}{l}\text { Responsible for waste collection, Transportation, \& } \\
\text { disposal for profit }\end{array}$ & $\begin{array}{l}\text { Responsible for waste collection, } \\
\text { Transportation, \& disposal for profit }\end{array}$ \\
\hline 13 & $\begin{array}{l}\text { Kyuriit } \\
\text { Cleaners Nig. } \\
\text { Ltd. }\end{array}$ & $\begin{array}{l}\text { Responsible for waste collection, Transportation, \& } \\
\text { disposal for profit }\end{array}$ & $\begin{array}{l}\text { Responsible for waste collection, } \\
\text { Transportation, \& disposal for profit }\end{array}$ \\
\hline
\end{tabular}

Table 4:- Roles and Responsibilities of the Agencies Responsible for Solid Waste Management

Source: 1.KEPA, (2010), 2. Field survey (2016) 
ISSN No:-2456-2165

\begin{tabular}{|c|c|c|c|c|c|c|c|c|c|c|c|c|c|c|c|}
\hline Agencies & $\begin{array}{l}\underset{\Delta}{\Delta} \\
\underset{I}{\mid l}\end{array}$ & 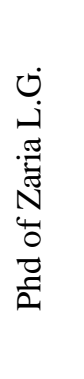 & 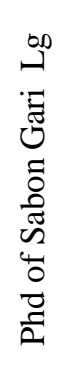 & 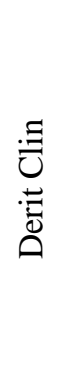 & 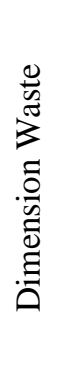 & 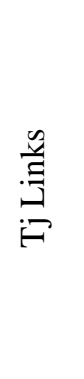 & $\begin{array}{l}\tilde{U} \\
\text { Q }\end{array}$ & 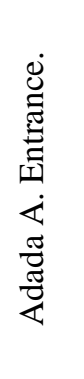 & 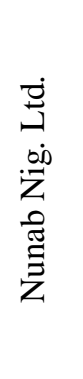 & 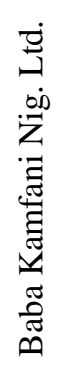 & 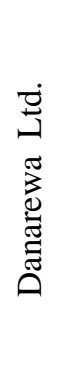 & 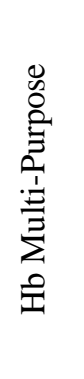 & 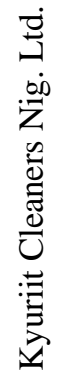 & $\frac{m}{\pi}$ & $\stackrel{\Xi}{\stackrel{\Xi}{\Xi}}$ \\
\hline KEPA & 1 & 1 & 1 & 1 & 1 & 1 & 1 & 1 & 1 & 1 & 1 & 1 & 1 & 12 & 0.92 \\
\hline $\begin{array}{c}\text { Phd of Zaria } \\
\text { LG }\end{array}$ & 1 & 1 & 2 & 2 & 2 & 2 & 2 & 2 & 2 & 2 & 2 & 2 & 2 & 1 & 0.08 \\
\hline $\begin{array}{l}\text { Phd of Sabon } \\
\text { Gari LG }\end{array}$ & 1 & 2 & 1 & 2 & 2 & 2 & 2 & 2 & 2 & 2 & 2 & 2 & 2 & 1 & 0.08 \\
\hline Derit Clin & 1 & 2 & 2 & 1 & 2 & 2 & 2 & 2 & 2 & 2 & 2 & 2 & 2 & 1 & 0.08 \\
\hline $\begin{array}{c}\text { Dimensions } \\
\text { Waste }\end{array}$ & 1 & 2 & 2 & 2 & 1 & 2 & 2 & 2 & 2 & 2 & 2 & 2 & 2 & 1 & 0.08 \\
\hline TJ Links & 1 & 2 & 2 & 2 & 2 & 1 & 2 & 2 & 2 & 2 & 2 & 2 & 2 & 1 & 0.08 \\
\hline Pect & 1 & 2 & 2 & 2 & 2 & 2 & 1 & 2 & 2 & 2 & 2 & 2 & 2 & 1 & 0.08 \\
\hline $\begin{array}{c}\text { Adada Akara. } \\
\text { Enterprises }\end{array}$ & 1 & 2 & 2 & 2 & 2 & 2 & 2 & 1 & 2 & 2 & 2 & 2 & 2 & 1 & 0.08 \\
\hline $\begin{array}{l}\text { Nunab Nig. } \\
\text { Ltd. }\end{array}$ & 1 & 2 & 2 & 2 & 2 & 2 & 2 & 2 & 1 & 2 & 2 & 2 & 2 & 1 & 0.08 \\
\hline Baba Kamfani & 1 & 2 & 2 & 2 & 2 & 2 & 2 & 2 & 2 & 1 & 2 & 2 & 2 & 1 & 0.08 \\
\hline $\begin{array}{c}\text { Dan-Arewa } \\
\text { Nig. Ltd }\end{array}$ & 1 & 2 & 2 & 2 & 2 & 2 & 2 & 2 & 2 & 2 & 1 & 2 & 2 & 1 & 0.08 \\
\hline $\begin{array}{c}\mathrm{HB} \\
\text { Multipurpose }\end{array}$ & 1 & 2 & 2 & 2 & 2 & 2 & 2 & 2 & 2 & 2 & 2 & 1 & 2 & 1 & 0.08 \\
\hline $\begin{array}{c}\text { Kyuriit } \\
\text { Cleaners Nig. }\end{array}$ & 1 & 2 & 2 & 2 & 2 & 2 & 2 & 2 & 2 & 2 & 2 & 2 & 1 & 1 & 0.08 \\
\hline $\mathrm{N}=13$ & 12 & 2 & 2 & 2 & 2 & 2 & 2 & 2 & 2 & 2 & 2 & 2 & 2 & & $\mathrm{GM}=0.14$ \\
\hline Mean & 0.92 & 0.08 & 0.08 & 0.08 & 0.08 & 0.08 & 0.08 & 0.08 & 0.08 & 0.08 & 0.08 & 0.08 & 0.08 & $\begin{array}{c}\mathrm{GM}= \\
0.14\end{array}$ & $\begin{array}{c}\text { The overall } \\
\text { grand mean } \\
\text { score } 0.14+ \\
0.14=0.28 / 13 \\
=0.01\end{array}$ \\
\hline
\end{tabular}

Table 5:- Rating of Inter-Agency Relationships among Agencies Involved in Solid Waste Management Source: Field Survey, 2016

Looking at the table above, for vertical and horizontal relationship, it can be seen that only the mean scores between KEPA and the rest of the agencies earns 0.92. However, the Grand mean score for the vertical and horizontal relationship which is 0.01 , implies that the relationship among the agencies is very little, which indicates that there is lack of coordination among them. 


\begin{tabular}{|c|c|c|c|c|c|c|c|c|}
\hline S/No & Variables & UD & SD & $\mathbf{D}$ & $\mathbf{A}$ & SA & $\mathrm{N}=13$ & $\begin{array}{l}\text { Mean } \\
\text { Score }\end{array}$ \\
\hline 1 & $\begin{array}{l}\text { Your activities are properly coordinated with } \\
\text { the activities of other institutions }\end{array}$ & 0 & 2 & 16 & 3 & 8 & 29 & 2.23 \\
\hline 2 & $\begin{array}{c}\text { Institutions comply with joint decisions taken } \\
\text { by stakeholders in solid waste management }\end{array}$ & 0 & 0 & 20 & 0 & 12 & 32 & 2.46 \\
\hline 3 & $\begin{array}{c}\text { The following means by which the activities of } \\
\text { agencies can properly be integrated are } \\
\text { obtainable in Zaria Urban Area }\end{array}$ & & & & & & & \\
\hline 4 & A coordinating agency & 0 & 0 & 0 & 20 & 12 & 32 & 2.46 \\
\hline 5 & $\begin{array}{l}\text { There is an integrated plan for solid waste } \\
\text { management in the area }\end{array}$ & 0 & 7 & 6 & & 8 & 21 & 1.61 \\
\hline 6 & $\begin{array}{c}\text { Constant inter-agency meetings, consultation, } \\
\text { dialoguing do take place }\end{array}$ & 0 & 0 & 16 & 0 & 12 & 28 & 2.15 \\
\hline 7 & $\begin{array}{c}\text { There is effective inter-agency communication } \\
\text { and information sharing }\end{array}$ & 0 & 4 & 10 & 9 & 0 & 23 & 1.76 \\
\hline & Grand Mean & & & & & & & 2.11 \\
\hline
\end{tabular}

Table 6:- Mean Responses of the Respondents on Collaboration among Agencies Involved in Solid Waste Management Source: Field survey, 2016

The analysis of the variables on table 6 , shows that the respondents disagreed with most of the items above. For instance, the respondents disagreed with items 1 and 3 whose mean scores were 2.23 and 2.46 respectively. While the grand mean score is 2.11 and from the decision rule it implies that collaboration among the agencies within the study area is very low. Therefore, there is need to develop an efficient means of collaboration among them.

\begin{tabular}{|c|c|c|c|c|c|c|c|c|}
\hline S/No & Variables & UD & SD & D & A & SA & N=13 & Mean Score \\
\hline $\mathbf{1}$ & $\begin{array}{c}\text { There are regular joint } \\
\text { workshops/seminars organized by } \\
\text { institutions/agencies }\end{array}$ & 0 & 0 & 16 & 6 & 0 & 22 & 1.69 \\
\hline $\mathbf{2}$ & $\begin{array}{c}\text { There is regularity of formal } \\
\text { meetings/consultations among } \\
\text { stakeholders to discuss solid waste } \\
\text { management issues }\end{array}$ & 0 & 0 & 20 & 3 & 0 & 23 & 1.76 \\
\hline $\mathbf{4}$ & $\begin{array}{c}\text { The meetings held by stakeholders are } \\
\text { effective }\end{array}$ & 0 & 0 & 16 & 6 & 0 & 22 & 1.69 \\
\hline & $\begin{array}{c}\text { Stakeholders regularly participate in } \\
\text { the joint workshops/seminars }\end{array}$ & 0 & 4 & 8 & 9 & 0 & 21 & \\
\hline
\end{tabular}

Table 7: Mean Responses of the Respondents on Consultation among Agencies Involved in Solid Waste Management. Source: Field Survey, (2016)

The analysis of the variables above shows that majority the respondents disagree with items 1-4 because all the mean scores are less than 3.00 and grand mean which is 1.68 also shows that there is very little consultation among the agencies responsible for solid waste management in the study area.

\begin{tabular}{|c|c|c|c|c|c|c|c|c|}
\hline S/No & Variables & UD & SD & D & A & SA & N=13 & Mean score \\
\hline $\mathbf{1}$ & $\begin{array}{c}\text { Regularity of accessibility of up-to-date } \\
\text { information from one stakeholder to another }\end{array}$ & 0 & 1 & 16 & 9 & 0 & 26 & 2.00 \\
\hline $\mathbf{2}$ & $\begin{array}{c}\text { There is availability of internet } \\
\text { service/interactive website in the agencies }\end{array}$ & 0 & 8 & 2 & 6 & 0 & 16 & 1.23 \\
\hline $\mathbf{3}$ & $\begin{array}{c}\text { The use of means of communication to } \\
\text { disseminate information to other agencies. }\end{array}$ & & & & & & \\
\hline & a. Public awareness campaign & 0 & 7 & 4 & 6 & 0 & 17 & 1.30 \\
\hline & b. Mass media & 0 & 8 & 6 & 0 & 0 & 14 & 1.07 \\
\hline & ICT (Internet/Telephone) & 0 & 7 & 6 & 3 & 0 & 16 & 1.23 \\
\hline
\end{tabular}

Table 8:- Mean Responses of the Respondents on Exchange of Information among Agencies Involved_in Solid Waste Management.

Source: Field Survey, (2016) 
The analysis of the variables on table 8 shows that the respondents disagreed with most of the items above. Even though item 1 which is regularity of accessibility of up to date information from one stakeholder to another scored 2.00 , it is still below the acceptable range. The grand mean score which is 1.36 implies that there is lack of effective exchange of information among the agencies.

\begin{tabular}{|c|c|c|c|c|c|c|c|c|}
\hline S/No & Variables & UD & SD & $\mathbf{D}$ & $\mathbf{A}$ & SA & $\mathrm{N}=13$ & $\begin{array}{c}\text { Mean } \\
(\mathbf{X})\end{array}$ \\
\hline 1 & $\begin{array}{l}\text { Unsanitary disposal of waste } \\
\text { especially by informal operators }\end{array}$ & & & & 30 & 12 & 42 & 2.33 \\
\hline 2 & Lack of users' satisfaction & & & & 24 & 20 & 44 & 3.38 \\
\hline 3 & $\begin{array}{l}\text { Contraventions of the regulations } \\
\text { made by government }\end{array}$ & & & & 15 & 32 & 47 & 3.61 \\
\hline 4 & $\begin{array}{l}\text { Lack of linkage among the } \\
\text { different actors especially the } 2 \\
\text { local government authorities }\end{array}$ & & & & 9 & 40 & 49 & 3.76 \\
\hline 5 & Lack of sustainability & & & & 3 & 48 & 51 & 3.92 \\
\hline 6 & Poor communication & & & & 6 & 44 & 50 & 3.84 \\
\hline 7 & Lack of negotiations/consensus & & & & 24 & 20 & 44 & 3.38 \\
\hline 8 & $\begin{array}{l}\text { Lack of formal recognition for } \\
\text { some of the stake holders }\end{array}$ & & & & 33 & 8 & 41 & 3.15 \\
\hline 9 & $\begin{array}{l}\text { Duplication of roles and } \\
\text { responsibilities }\end{array}$ & & & & 21 & 24 & 25 & 1.92 \\
\hline 10 & $\begin{array}{l}\text { Conflicts of functions among } \\
\text { agencies with similar functions }\end{array}$ & & & & 18 & 28 & 46 & 3.53 \\
\hline 11 & $\begin{array}{c}\text { Lack of clear-cut jurisdictional } \\
\text { boundaries }\end{array}$ & & & & 9 & 40 & 49 & 3.76 \\
\hline \multirow[t]{2}{*}{12} & Competition for supremacy & 2 & & & 24 & 12 & 36 & 2.76 \\
\hline & Grand Mean & & & & & & & 3.27 \\
\hline
\end{tabular}

Table 9:- Mean Responses of the Respondents on their Perception of the Effects of Absence of a Well-Coordinated Solid Waste Management System in the Study Area.

Source: Field Survey, (2016)

The analysis of the variables in table 20 indicates that the respondents agreed with all the items and the grand mean score is 3.27 , therefore, it is concluded that the problems of solid waste management present in the study area are as a result of the absence of a well-coordinated solid waste management system.

\section{CONCLUSION}

It is clear from the findings of this study that the results of analysis using indicators of coordination among the agencies involved in solid waste management indicated in efficient coordination. For instance, the result of the analysis using the two points ordinal scale on inter agency relationship indicated that relationship among the agencies is very little going by the decision rule. Analysis of variables on collaboration also revealed low collaboration among the agencies. Results of analysis on consultation also indicated little consultation among the agencies. Likewise, the low mean score of the result of analysis of the variables on information exchange among the agencies signified inefficient coordination among them. Finally, the last mean score by the respondents in table 9 indicated they have all agreed that the problems of solid waste management in the study area are mostly as a result of the absence of a well- coordinated solid waste management system. In the light of these, therefore, the level of coordination among these agencies can be said to be in efficient, which have also resulted to problems such as ineffective enforcement of regulations,_lack of physical infrastructure provision, irregular evacuation of solid waste collection points etc. However, if all the problems as revealed by the study are resolved, the activities of the agencies responsible for solid waste management will be improved in the study area. Therefore, efforts should be made by the Government agencies in collaboration with other stakeholders to implement the recommendations made in this Study.

\section{RECOMMENDATIONS}

From the issues discussed in this paper, it is worthwhile to recommend as follows

$>$ There is need to prepare a well-coordinated and common solid waste management plan for common implementation by all stakeholders, which will guide policy formulation and coordinate all urban solid waste management issues within the urban area. 
Information exchange should be improved by providing effective means of communication among the institutions in the areas of public awareness campaigns, regularity of accessibility of the institutions to up to date information from other institutions.

Consultation should also be improved by organizing formal meetings and participation in joint workshops / seminars to discuss issues related to solid waste management as well as formulate strategies to solving existing problems and preventing future ones.

$>$ The institutions should make sure they improve collaboration among them through proper coordination and regulation of their activities as well as enforcing compliance to joint decisions taken by stakeholders.

$>$ There is an urgent need for Kaduna State Environmental Protection Agency (KEPA) and the two local government authorities that is Zaria and Sabon-Gari local Government Authorities, to linkup with one another, as well as organize regular problem solving meetings with other stakeholders.

\section{REFERENCES}

[1]. Galadima, A. ( 2012). Evaluation of the Institutional Framework of Urban Transport in Kaduna Metropolis, Unpublished M.Sc Urban Management thesis, Department of Urban and Regional Planning, $\mathrm{ABU}$, Zaria.

[2]. Onyanta, A.A. (2006). The Specificity of Governance; Solid Waste Management in Abuja, Nigeria. Licentiate Thesis. Department of Human Geography, Stockholm University, Sweden.

[3]. Schubeler, P. K. Wehrle and Christen, J. (1996). Conceptual Framework for Municipal Solid Waste Management in Low Income Countries. Working Paper No. 9, UMP(LTNDP/UNCHS/World Bank) and SDC (Swiss Agency for Development And Cooperation) St. Gallen, Switzerland,SKAT. http://WBLN0018.worldbank.org

[4]. Stare, M. (2005). Decentralised Service Provision in Theory and Practice, The Agency Structure of The Solid waste Management of Zaria, Nigeria, (Thesis 10 credits, Specialised Course in Human Geography, Stockholm University)

[5]. Taylor, P. (2000). UNCHS Habitat the Global Campaign for Good Governance. Environment and Urbanisation, Vol. 11, No.2, 2000.

[6]. Urban Development Bank of Nigeria Plc (1998), Urban Solid Waste Management Scheme (National Stakeholders Consultative Workshop) for PTF November 23 - 27, 1998. Abuja, Nigeria.

[7]. Yahaya, A. (1999). Partnership Approach to Solid Waste Management: A case Study of Sokoto Metropolis. Unpublished M.Sc. Urban Management thesis, Department of Urban and Regional Planning, ABU, Zaria. 